The Address of the Eye 



\title{
The Address of the Eye
}

\author{
A PHENOMENOLOGY OF \\ FILM EXPERIENCE
}

Vivian Sobchack

\begin{tabular}{llllllllllllllllllllllll}
\hline & $R$ & $I$ & $N$ & $C$ & $E$ & $T$ & $O$ & $N$ & U & $N$ & I & V & E & $R$ & S & I & T & Y & P & $R$ & E & S & $S$
\end{tabular}

P R I N C E T O N, N E W J E R S E Y 
Copyright (C) 1992 by Princeton University Press Published by Princeton University Press, 41 William Street,

Princeton, New Jersey 08540 In the United Kingdom: Princeton University Press, Oxford All Rights Reserved

Library of Congress Cataloging-in-Publication Data Sobchack, Vivian Carol. The address of the eye : a phenomenology of film experience / Vivian Sobchack. p. $\mathrm{cm}$. Includes bibliographical references and index. ISBN 0-691-03195-9 : $\$ 35.00$

1. Motion pictures-Philosophy. I. Title. PN 1995.S54 1992 791.43'01-dc20 91-21402 CIP

This book has been composed in Linotron Palatino

Princeton University Press books are printed on acid-free paper, and meet the guidelines for permanence and durability of the Committee on Production Guidelines for Book Longevity of the Council on Library Resources

Printed in the United States of America by Princeton University Press, Princeton, New Jersey

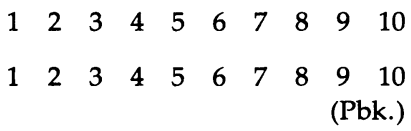




\section{TO RICHARD L. LANIGAN}

FOR TEACHING ME WHAT I ALWAYS

A L REA DY KN E W 
As soon as we see other seers ... henceforth, through other eyes we are for ourselves fully visible. . . . For the first time, the seeing that I am is for me really visible; for the first time I appear to myself completely turned inside out under my own eyes.

Maurice Merleau-Ponty

The Visible and the Invisible

\begin{abstract}
A being which is not the object of another being . . . presupposes that no objective being exists. . . . To be sensuous, i.e., to be real, is to be an object of sense, a sensuous object, and thus to have sensuous objects outside oneself, objects of one's sense perceptions.

KARL MARX

Early Writings
\end{abstract}


